\title{
Twenty-nine years of the BIR annual survey part 1: technological change
}

\section{Luke Tredinnick}

Abstract: This paper is the first part of a review of the Business Information Review Annual Survey, which has been published annually since 1991. The paper explores technological change as it has been revealed by the surveys. It uses a combination of content and thematic analysis to develop six key themes, which are discussed by reference to the original surveys: the telling case of CD ROMs; the Internet and the World Wide Web; changing information formats; the impact of digital technologies on information work; intranets and knowledge management, and newer technologies. The paper aims to summarise and consolidate longitudinal trends revealed by the survey, act as a guide to the rich data contained within the surveys themselves, and provide a testament to the wealth of professional experience captured in the BIR Annual Surveys. Its findings relate to the nature of technological change and the incorporation of new technologies by the information and knowledge management profession.

\subsection{Introduction}

The Business Information Review (BIR) Annual Survey is the world's longest-running research into trends in the business information sector. Since 1991 it has provided an invaluable map to changes in business information work and the contexts within which that work takes place.

From the outset it was recognised that the BIR Annual Survey could provide useful longitudinal data. In 1993 for example it was written that "as the survey moves into its third year, it becomes possible to start tracking changes in the use of business information, as well as documenting the emergence of new trends" (Headland Press, 1993: 2). Since then individual surveys have often made observations concerning short- and medium-term trends, and in 2000 the report included a reflection on the first ten years of findings (Smith, 2000: 19 - 21). However there has been no systematic summary of the changes revealed by the survey over the three decades of its publication. This review seeks to close that gap, analysing what almost three decades of the BIR Annual Survey reveals about how information work has changed, and exploring what this implies about the future. It is divided into two parts. The first part of this review presented in this paper addresses technological change; the second part, which will be presented in the next issue of Business Information Review, addresses changes to the nature of information work.

Taken together the surveys represent an incredibly rich data-source. Twenty-seven surveys have been published to 2018, comprising some 497 pages, 500 data tables and diagrams, and around 250,000 words. Reading them in sequence makes for an interesting experience, impressing the amount of change through which business information work has gone, but also strong continuities in key concerns, challenges, and values underlying the profession. This review can only touch on the richer detail that emerges in the rich data of the surveys themselves, and there is much to discover from returning to the original reports. This paper is therefore intended as a summary of key trends within the survey rather than a comprehensive review, and readers are encouraged to followup on key issues within the annual surveys themselves.

This review uses content and thematic analysis to explore change over time. The published surveys between 1991 and 2018 were read in-depth, and the data was coded according to an ad hoc scheme reflecting the shifting priorities of the surveys. From this coding six key themes were developed for discussion in this paper:

- Theme 1: The telling case of CD ROMs

- $\quad$ Theme 2: The Internet and the World Wide Web

- Theme 3: Changing information formats

- Theme 4: The impact of digital technologies on information work

- Theme 5: Intranets and knowledge management

- Theme 6: Newer technologies 
The aims of this paper are threefold. In the first place it aims to summarise and consolidate longitudinal trends in the development of business information services over a period of very rapid technological change between 1991 and 2018. In the second place it aims to act as a guide to the rich data that is contained within the surveys themselves, by highlighting where particular issues first emerge, and how they develop through the years. Finally it aims to provide a testament to the wealth of professional experience than has been captured through the annual snapshots of the profession. Over the past thirty years hundreds individuals have taken part in the BIR Annual Survey. The success of the Annual Survey has depended on the insights gained from the wider professional community.

\subsection{Overview of the Business Information Review Annual Survey}

Like any long-running piece of research the BIR Annual Survey has undergone a number of changes in scope, focus, methodology and authorship. It was first published in 1991 with the expressed aim to "establish which products and services are used most heavily in UK business libraries and information departments" (Headland Press, 1991: 11). Since then the survey has outgrown this original narrow focus on resources, products and services. This section briefly recounts the ways in which the survey itself has developed through its history, and what this reveals about the changing nature of information work.

\subsection{BIR Annual Survey research design}

The BIR Annual Survey has been published every year between 1991 and 2018 with two exceptions. The 1994 survey appeared in January 1995, and was followed later in the same year by the publication of the 1995 survey. After this there was a gap of two years, with the next survey appearing in 1997. Both exceptions to the annual publication appear to be the result of a gradual slippage in the publishing schedule.

There has been a considerable continuity of authorship across the twenty-seven published reports (see: Appendix 1). Between 1991 and 2001 the survey was conducted and written by Gerry Smith (initially under the byline of Headland Press and Headland Business Information). From 2002 to 2016 the survey was written and conducted by Allan Foster and Pam Foster (2002 - 2003), Pam Foster and Allan Foster (2004 - 2006), and Allan Foster (2007 - 2016). Since 2016 the research has been undertaken by Denise Carter of DCsion Consult. This continuity in authorship has resulted in greater consistency in methodology and focus than might be expected for such a long-running piece of research. Changes to the research design have tended to be evolutionary rather than revolutionary and reflect the changing contexts within which the survey has been undertaken. Areas of inquiry have been added and removed from the research as they emerge in and fade from wider professional concerns. Indeed in many ways the evolution of the research design of the surveys is as much a guide to changes in the sector as the research data itself, exemplifying the issues at the forefront of professional concern over time.

Nevertheless there has been one major change in approach and several small changes in focus over the history of the research. Between 1991 and 2006 the research was undertaken using survey methodology; for the majority of this time these were postal questionnaires mailed to publisher or information service subscriber lists, but from 2003 the postal questionnaire was supplemented by an electronic questionnaire distributed via special interest groups (Foster \& Foster, 2003), and from 2005 it was supplemented by a smaller survey targeted at key information professionals in the corporate sector (Foster \& Foster, 2005). From the late 1990s there was a significant decline in the response rate to the general survey (see: figure 1), and by 2006 the continuing viability of this methodology was becoming questionable. This prompted a change in approach; writing about this fundamental rethink Allan Foster wrote: 
This arrangement staggered on for a number of years before, in 2006, the responses became more uneven, prosaic, arbitrary and less and less representative of the corporate business environment where much of the interesting service development was happening. (Foster, 2008: 14)

From 2007 the BIR Annual Survey adopted a rich, qualitative and in-depth approach using interviews with key senior professionals as its principle research instrument, supplemented by insights from the professional literature. It has continued to use interviews ever since, however in 2017 a smaller scale survey was reintroduced to compliment the qualitative findings. This change in methodology and approach makes it more difficult to draw direct comparisons between the two periods, although it is still possible to draw inferences across the data.

\section{Figure 1: Responses over time to the general questinnaire}

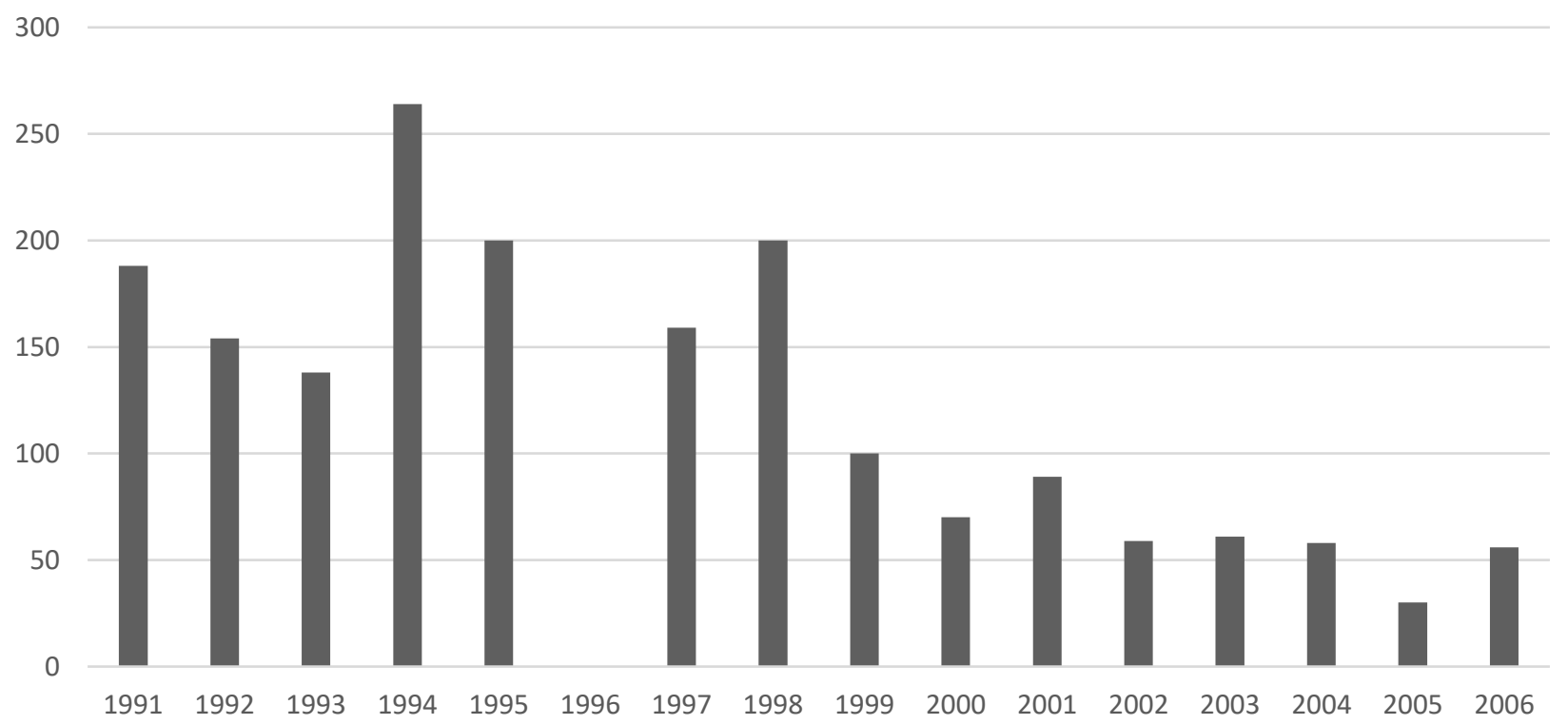

This change from surveys to interviews accompanied a shift in scope and focus. When it was launched in 1991 the BIR Annual Survey was tightly focussed on products and services, and much of the data concerned the specific resources in use within business information centres and libraries. The survey quickly outgrew this narrow focus, and began to investigate issues of more strategic, policy and management concern within its first few years. The use of open questions inviting rich qualitative responses increased over time, and responses from these began to feature more significantly in the research findings from the mid-1990s. The switch to interviews in 2007 was therefore a culmination of changes already underway in the development and design of the research, consolidating the gradual shift in focus and scope from products and services to strategic, policy and management issues. The 2007 report explained:

The concentration in this Survey is on strategic issues - the place of the information service in the organization, the role of knowledge management in the business, whether or not to provide training in the use of desk top data sources, the possible use of outsourcing or offshoring and the use of performance measures in assessing the value the information service adds to the business (Foster, 2007).

The switch to interviews also narrowed the sector scope of the survey. Between 1991 and 2006 the survey covered a range of information sectors - predominantly corporate, academic and public libraries. The proportion of respondent from different sectors remained relatively stable over time (figure 2) however towards the end of this period the corporate sector became significantly more important to the survey. From 2007 the survey began to addressed trends within the corporate sector in order to provide "a very clear focus to the survey and allows a measure of in-depth comparison and benchmarking which has proved difficult in the past (Foster, 2007: 14). It has largely retained 
this narrower focus since. More recently the research has expanded its geographical scope; in 2017 the survey reported that "The breadth of the survey is now truly international, with respondents from UK, Europe, Asia, Australia and North America" (Carter, 2017: 122). The shifting sampling strategy makes it more difficult to draw reliable inferences from the statistical data over time, however the duration of the research mitigates some of these issues. Where it is possible to disaggregate subsamples this review has focussed on responses from the corporate sector, in keeping with the current focus of the BIR Annual Survey.

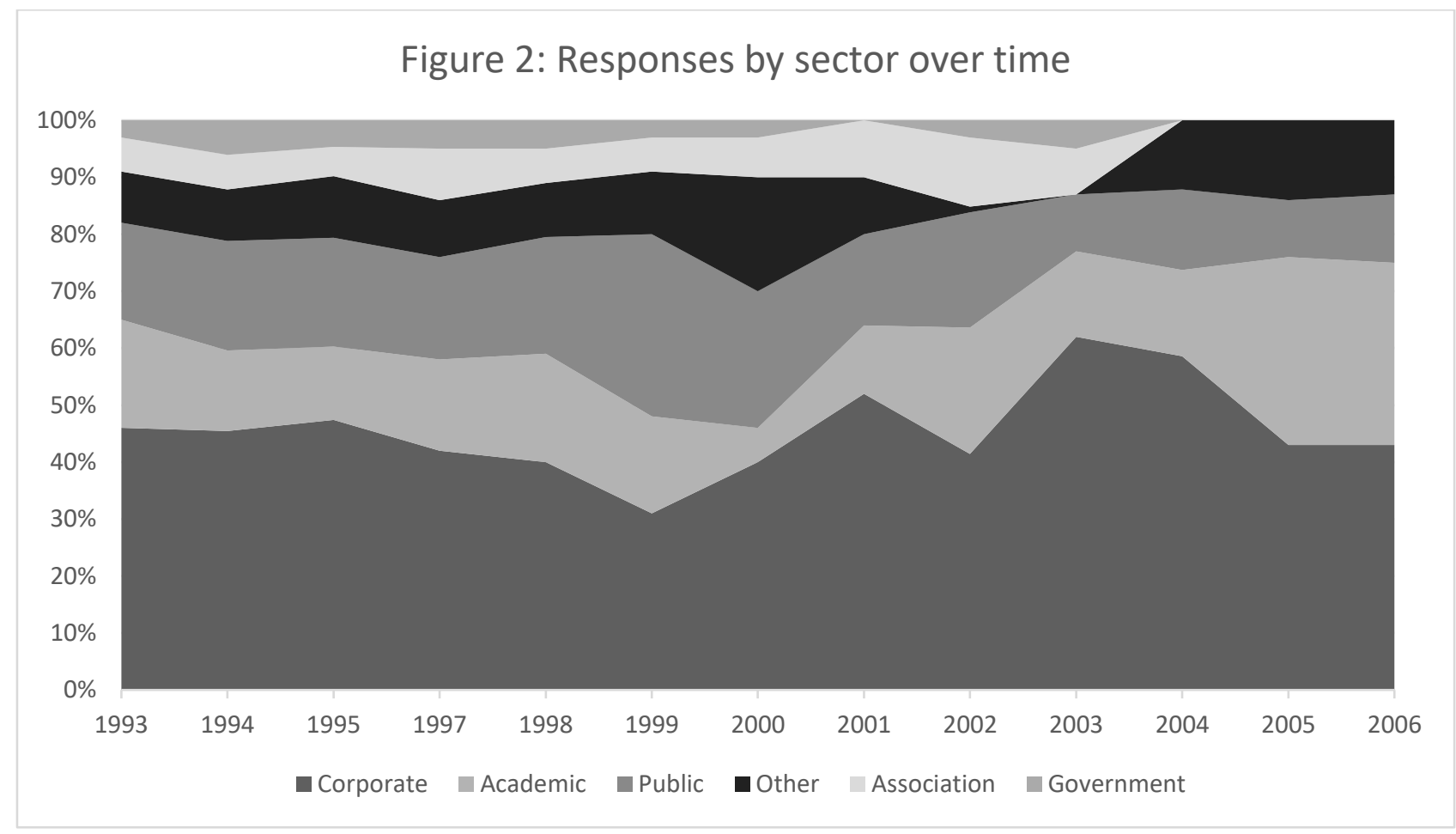

From 2007 participants in the survey interviews and from 2017 survey questionnaire are recorded by sector; the distribution is shown in figure 3 below.

Figure 3: Sector distribution over time

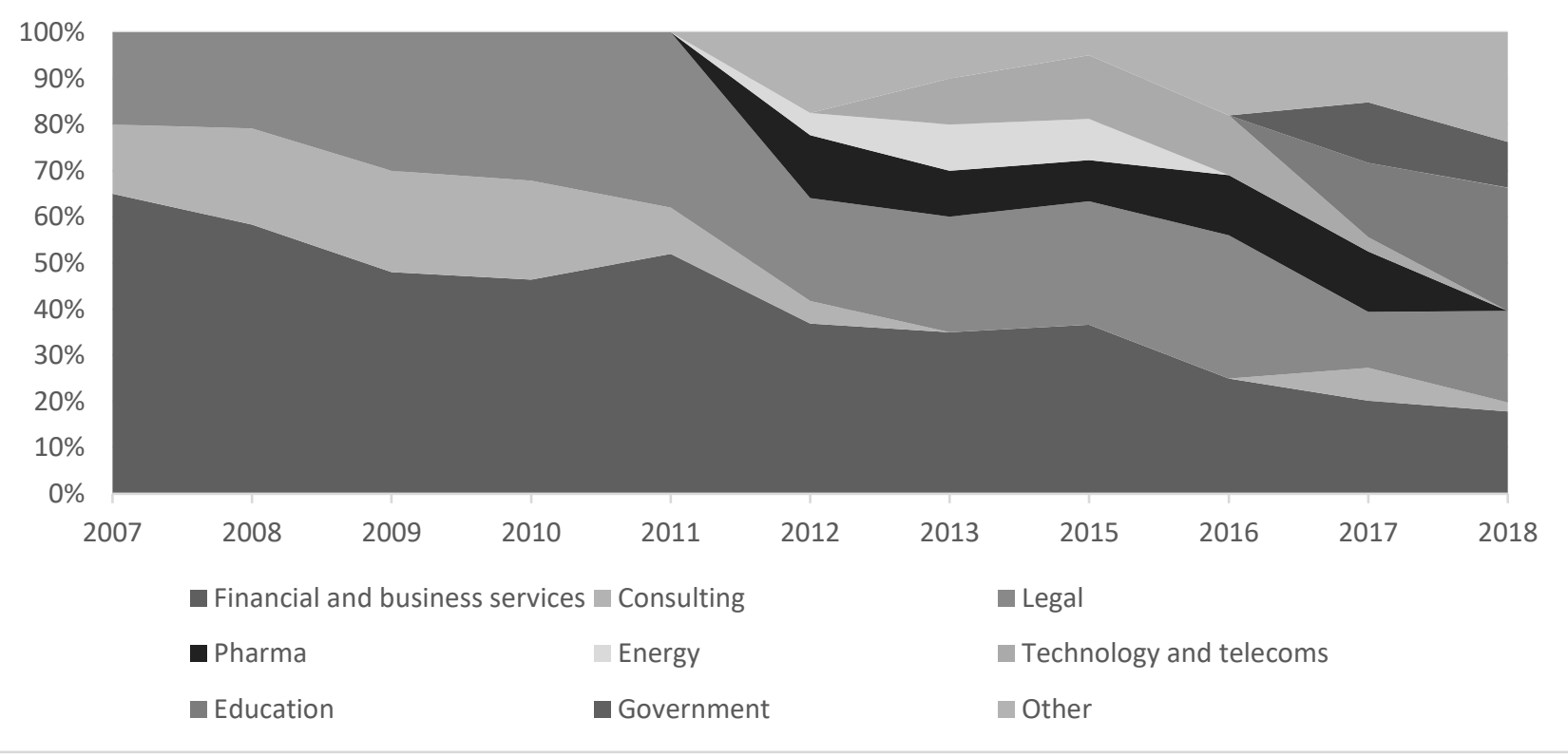


Over its entire run almost 2000 completed questionnaires and over 200 interviews have been included in the research. Although participation in the research has always been anonymous, we are aware that many of the participants in the BIR Annual Survey have lent their insights and expertise over many years, and the research has been indebted to and dependent on everyone who has taken part in it.

\subsection{General observations}

Longitudinal sector trends are captured in the data generated by the research and these are discussed below and in the second part of this review to be published in the next issue. However they are also captured in the changes to the way in which the research has been conducted. The topics covered by the research are themselves a map to the shifting terrain of professional work. But changes in methodology and focus also invite broader reflections.

In 1991 the profession was in the early stages of a long - ultimately perhaps much longer than expected - transition from traditional paper-based information resources to digital resources. Commercial online information systems were in widespread use in the commercial and academic sectors, but access was often restricted and information professionals had a gatekeeper role in access to sources and resources. Knowing where to find information and controlling that resource was paramount to professional responsibilities. The professional literature of the time was replete with concern with information seeking behaviour (e.g. Kauhltau, 1991). The close focus on resources of early surveys, which framed professional expertise as a matter of knowing and understanding the contexts for producing, storing, and retrieving business information, reflects the context within which information work was done at that time.

Towards the 2000s a preoccupation with knowing how to find information overtakes a preoccupation with where to find information. There is an increased focus on higher-level skills in business information work, and in commercial acumen. The professional literature of the late 1990s and early 2000s becomes more preoccupied with issues of information overload (particularly after: Reuters 1996), and information literacies (e.g. Andretta, 2005). At the same time the role of public and academic libraries was changing. The survey clearly reveals the ways in which business information services and collections provided by public library services become significantly less important to the sector as digital resources come to predominant. The survey also tracks the ways in which professional practice is influenced by these trends, with a significant decline in the kinds of routine business research, and an increasing emphasis on supporting and facilitating the use of information throughout the organisation, through training, involvement in developing intranets, knowledge management and other organisation wide initiatives, and through strategy and policy work. These trends are present within the surveys, but also implied by the ways in which the focus and methodology of the research changes over time. The greater emphasis on strategic, policy and management issues as the survey develops itself testifies to the greater role of information professionals in strategic and policy making within corporate organisations.

\subsection{Technological change}

Captured in the surveys has been a story of profound technological change that extends far beyond the business information sector, but which is nevertheless clearly reflected within it. The scope of this transformation is implied by mapping when new technologies first appear in the surveys. The Internet and email appear from 1993; browsers, the World Wide Web and Intranets from 1997; Websites from 1998; Google from 2002; Blogs from 2006; Web 2.0, wikis and Social Media from 2007; RSS and Facebook from 2008; Twitter and Big Data from 2012; Artificial Intelligence (Al) and Fake News From 2017, and blockchains from 2018. The scope of change is also revealed by when older technologies fall out of the survey. There is no mention of viewdata services after 1992, no substantive discussion of bulletin boards after 1999, or microfiches after 2002 . The search engines 
Yahoo and Northern Light disappear from 2004. The surveys capture a period of quite profound change to the profession and its practices that witnessed the emergence of the Internet and World Wide Web and the transition from traditional to digital resources.

As a part of this review a content analysis of the surveys was performed to measure the frequency of a handful of key technological terms; a summary of this presented in Appendix 2. Two interesting findings emerge from this analysis. In the first place it demonstrates shifting technological concerns as new tools emerge and replace older tools. In the second place, and perhaps more interestingly, the content analysis reveals the degree to which technology in general has been a shifting concern over time. Figure 4 below shows the frequency of all the technological terms included in the analysis. It reveals a peak around the year 2000 at which time technological issues came to dominat, followed by a significant decline over subsequent surveys. This clearly implies the disruptive nature of the Internet and World Wide Web. The diagram also shows an apparent peak emerging towards the 2010s reflecting mobile, social media, and emerging technologies such as artificial intelligence. Although some of the dips and peaks in the diagram reflect changing methodologies, samples and response rates, and although therefore the diagram is only indicative of change over time, it nevertheless presents a picture that is reflected also in the thematic analysis below. It illustrates quite how important the emergence of the World Wide Web was in information work at the turn of the millennium, and while it is impossible to extrapolate from the diagram to future trends, it implies that with emergence of $\mathrm{Al}$ in the next few years we may be on the brink of a fourth information revolution (see also: Carter, 2017; 2018).

\section{Figure 4: Frequency of tracked technology terms}

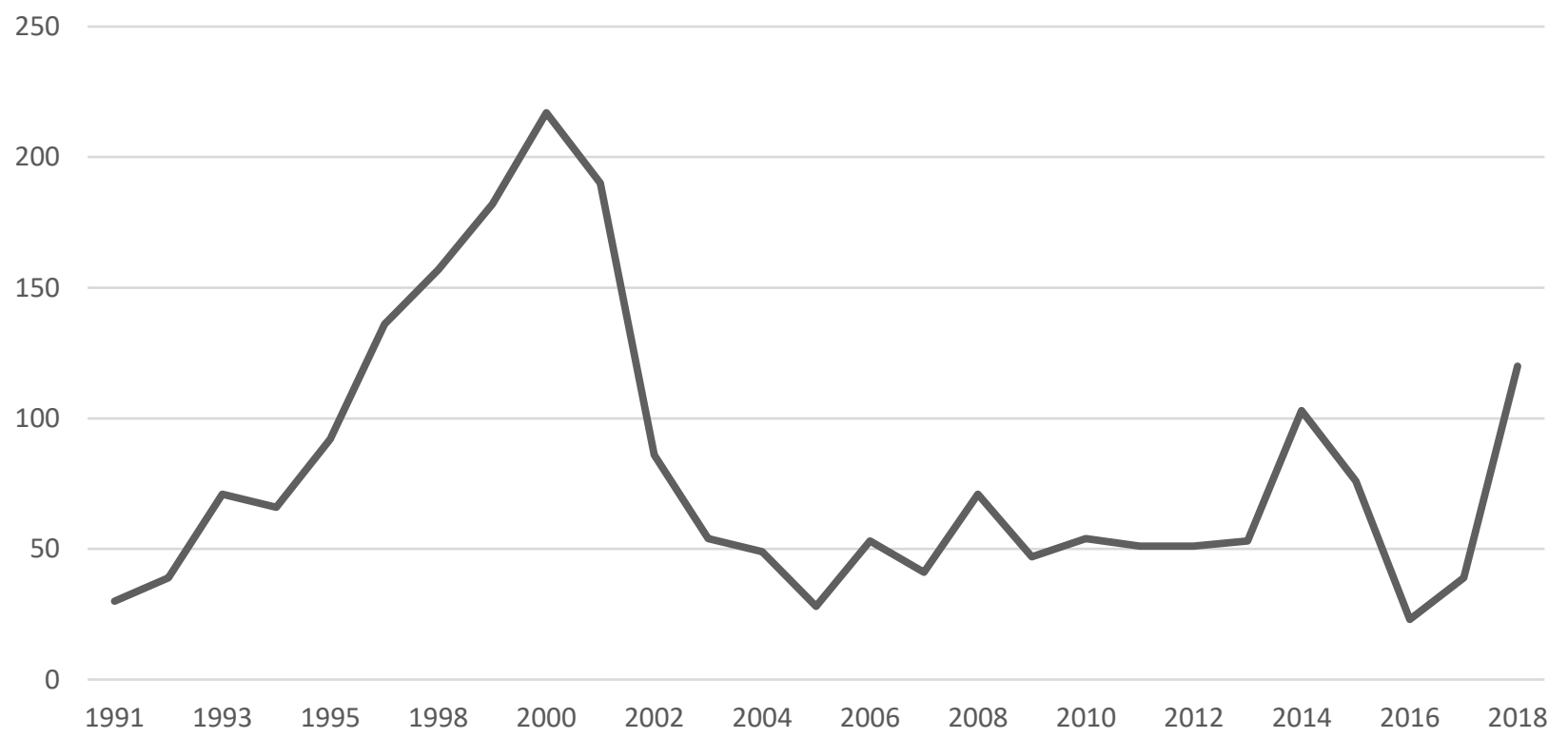

It is an exaggeration to suggest that the nature of business information work changed beyond recognition during the course of the surveys - the central importance of certain kinds of business information remain consistent through the surveys, and many of the challenges of information work discussed in the 1990s are remarkable similar to the challenges today as will be discussed in the second part of this review. Nevertheless the context within which that work is done have changed significantly. The key technological findings from the surveys are reproduced in Appendix 3 to illustrate this change. They illustrate both the degree to which technology has been a factor in emerging technological concerns, and the range of specific issues that have emerged.

This section explores a handful of key technological themes that have arisen in the thematic and content analysis. It examines how they emerge in the surveys, and what they imply about the future technologies of information work. Examining how the surveys addressed these changes at the time 
that they were taking place allows us to draw insights into and inferences about that the way in which technological change happens, and the role of information professionals in this process. Therefore this review concludes with some remarks on the nature of technological change as it is revealed by the BIR Annual Surveys.

\subsection{Theme 1: The telling case of CD ROMS}

When the survey began the business information world was still dominated by paper resources supplemented by dial-up online services. Of the fifteen questions asked in the first survey, only five addressed digital resources of any kind and many addressed print services that have long since ceased publication. The pressing technological issues revealed in the early surveys were the apparent glacial and selective adoption of CD ROM services.

The coverage of CD ROMs by the surveys makes an interesting case study. CD-ROMs dominate discussion of technology in the early surveys. Although now largely obsolete and their centrality in the survey is perhaps mostly an historical curiosity. However it also reveals interesting clues to the nature of technological change. The BIR Annual Survey tracked the use of CD ROM services and networked CD ROMS between 1991 and the early 2000s. At the beginning of this period the survey's noted that "the business library marketplace is currently dominated by talk of CD-ROM" (Headland Press, 1991). However the market penetration in information centres and libraries remained surprisingly low; a significant proportion of business libraries used no CD ROMs, and most used only a handful. Indeed the major finding of the first ever survey was this "low usage of CD-ROM" (Headland Press, 1991: 12), and the comparatively low uptake remained a consistent finding throughout early- and mid-1990s. By 1992 they had made "steady, if unspectacular progress" (Headland Press, 1992: 4), and by 1994 the survey confidently predicted that CD ROMs had "probably reached maximum penetration" with $46 \%$ of business libraries making no use of them at all (Headland Business Information, 1994). In fact the growth of CD ROMs continued for several more years, and found a key market in company financial data. Nevertheless a clear picture emerges of a technology that promised much, found useful application in a relatively limited number of contexts, and which rapidly faded from view.

The importance of CD ROMs to the early surveys reveals a number of persistent themes about technological change that recurs throughout the survey. New technologies tend to promise significant change but tend to find value in niche functions. Technological adoption is patchier, and takes longer than either is anticipated, or remembered when we consider and discuss their transformational effects retrospectively. Finally the nature of the change that new technologies eventually bring about is often overlooked at the time that it is taking place. This is a pattern that recurs through the BIR Annual Surveys.

\subsection{Theme 2: The Internet and the World Wide Web}

If CD ROMs largely failed to bring the promised benefits to business information work beyond a limited number of applications, the second of our technological themes promises to be more obviously and fundamentally transformational. The surveys begin to address the Internet and World Wide Web from 1993. At this time awareness of the Internet - by then about ten years old - was beginning to grow beyond academic contexts. This was partly a consequence of the still embryonic World Wide Web, and particularly the launch of more user-friendly web browser such as Mosaic in 1993 and Netscape in 1994. That the Internet features as early as 1993 highlights the technological awareness of business information professionals throughout the period covered by the surveys: emerging technology tends to feature in the surveys soon after they become more widely adopted. In this regard business information professionals are often seen to be on the cutting edge of technological change. 
But in 1993 the survey also reveals the patchy uptake of internet services that emerged with CD ROM, and also reveals the extent to which its potential to revolutionise information work was still largely unrecognised. In 1993 Only 7\% of respondents were using the Internet, and only 9\% had any plans to over the next year. The report questioned "the reluctance of our population to embrace technological innovation such as CD-ROM networking and the Internet" (Headland Press, 1993: 13) and stated:

If CD-ROM networking (see above) was the litmus test of library innovation in the early 1990s, its position in 1993 has been taken by the Internet, the revolutionary electronic network providing improved access to database hosts, as well as electronic mail and specialist bulletin boards. But, as the responses [...] above make clear, although the Internet might be the hot topic of 1993, our sample of business librarians have thus far shown little interest in it. (Headland Press, 1993: 8)

A year later the proportion of regular users had risen to $12 \%$ drawing the comment that "given the very small proportion of business librarians who use the Internet daily [...] it's difficult to understand the level of excitement it has generated" (Headland Business Information, 1995a). By 1995 the vast majority of respondents were still making no significant use of the Internet. However, this year's survey confidently predicted that "Internet use amongst business librarians in the UK is just about to take off" (Headland Business Information, 1995b). It is a prediction that proved accurate; when the next survey was published two years later, two thirds of respondents were making regular use of the internet (Smith, 1997). Over the next four years that steadily increased to universal access (see: Figure 5).

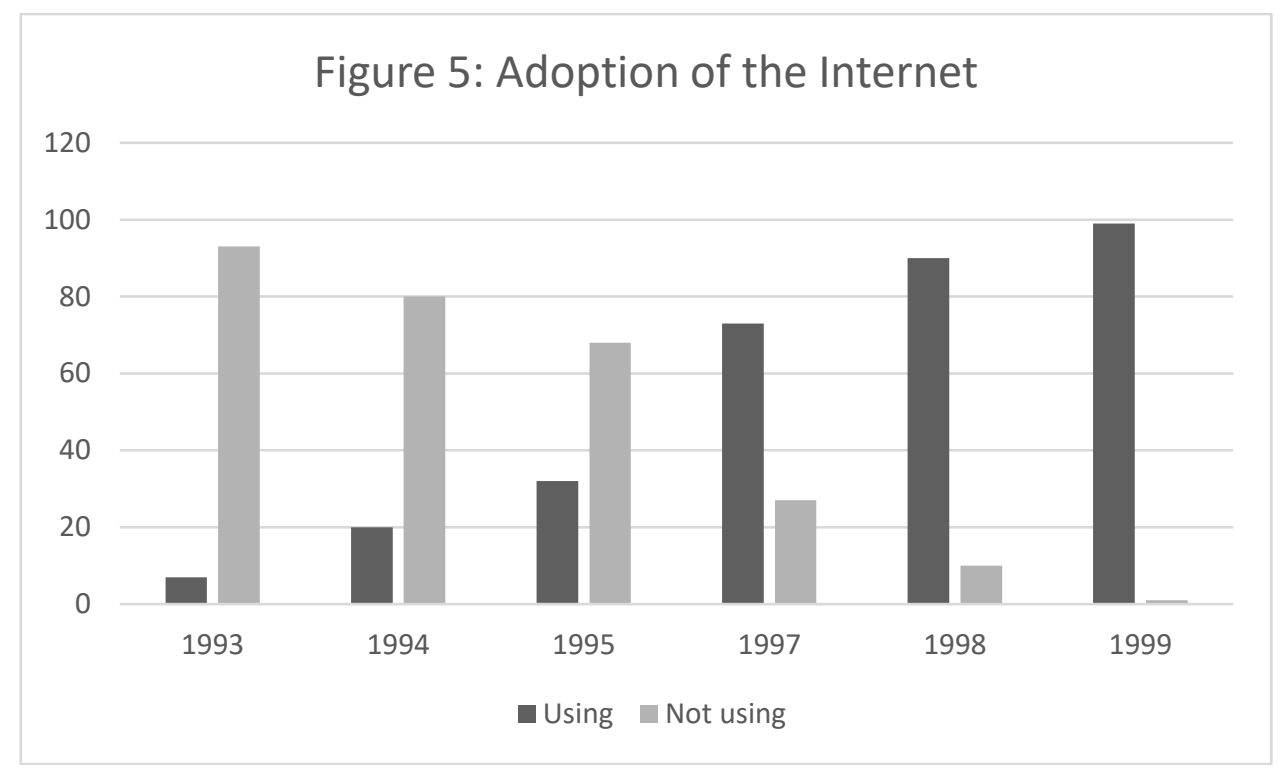

Not only was the uptake increasing, but the ways in which information professionals were using the internet and World Wide Web was also beginning to change. In the early 1990s the predominant use of the internet was for email; web browsing of any kind featured much less prominently. For the first time in 1997 accessing company websites topped the list of uses of the Internet, and continued to vie for top use until the question was asked for the last time in 1999 (Smith, 1997; 1999). In 1998 the survey reported that:

The killer application of the Web for business librarians is turning out to be company sites, for accounts, product data, and background information: the survey has picked-up a massive surge in the popularity of individual company websites (Smith, 1998: 16)

In reflection of these rapid changes to uptake and use of Internet and Web services, the 1997 survey included the follow wry comment: 
As recently as May 1995, a City Information Group (CIG) meeting concluded that the Internet had 'no useful role to play in business information at present'. Prominent speakers at the meeting described the Internet as a 'disaster' and 'a joke' [...] it is now clear with the benefit of hindsight that this dismissal of the Internet was premature" (Smith, 1997: 6)

Nevertheless throughout this period the Internet was framed by the survey as a complement to existing digital resources rather than their eventual replacement; the internet was not seen as a revolutionary technology but merely a new, more convenient way of completing some existing tasks. For example the survey reported in 1997 that "the jury is still out on the potential for the Internet in wider markets - UK business end-users and in particular, consumer markets" (Smith, 1997: 6). In this respect the fact that the Internet and CD ROMs are consistently discussed together in the surveys during the mid- and late-1990s highlights the extent to which the internet was framed as a format change, rather than a process change, reinforcing the picture that emergence in the surveys that the transformational effects of technological change are largely understood in retrospect.

The survey over this period also captures some of the broader context of the impact of the Internet and World Wide Web in the mid to late nineteen-nineties, such as for example the browser wars of the period, and the development of web search. In 1998 when the question was first asked two thirds of business librarians were still using the Nescape Navigator browser (Smith, 1998); a year later Microsoft Explorer had taken half of the market (Smith, 1999). By 2000 Microsoft Explorer dominated and the question was never asked again (Smith, 2000). Between 1997 and 2000 Alta Vista and Yahoo dominated web search. The survey commented that:

We feel that only Alta Vista's dominance of the library market is now pretty secure and that it can only increase its dominance with the launch of Alta Vista's UK version shortly after this survey was completed (Smith, 2000: 13).

Google had been a write-in choice of six respondents the same year. By the next it was dominating the search market in "one of the most striking changes ever recorded by this survey" (Smith, 2001: 13).

\subsection{Theme 3: Changing information formats}

The emergence of the Internet and World Wide Web had a significant influence on the ways in which digital information was delivered. Digital business information in 1991 predominantly meant online services and CD ROM (Headland Press, 1991); this was supplemented by viewdata services such as Prestel and Ceefax (Headland Press, 1992) and Fax (Headland press, 1993; Smith, 1999) and Email (Smith, 1999) services. By the end of the period the vast majority of digital business information was delivered via the World Wide Web. Between 1999 and 2001 the surveys capture this transition, with a rapid shift in preferences between client side Windows application to browser based database searching for accessing online information. The data is presented in Figure 6 below: 


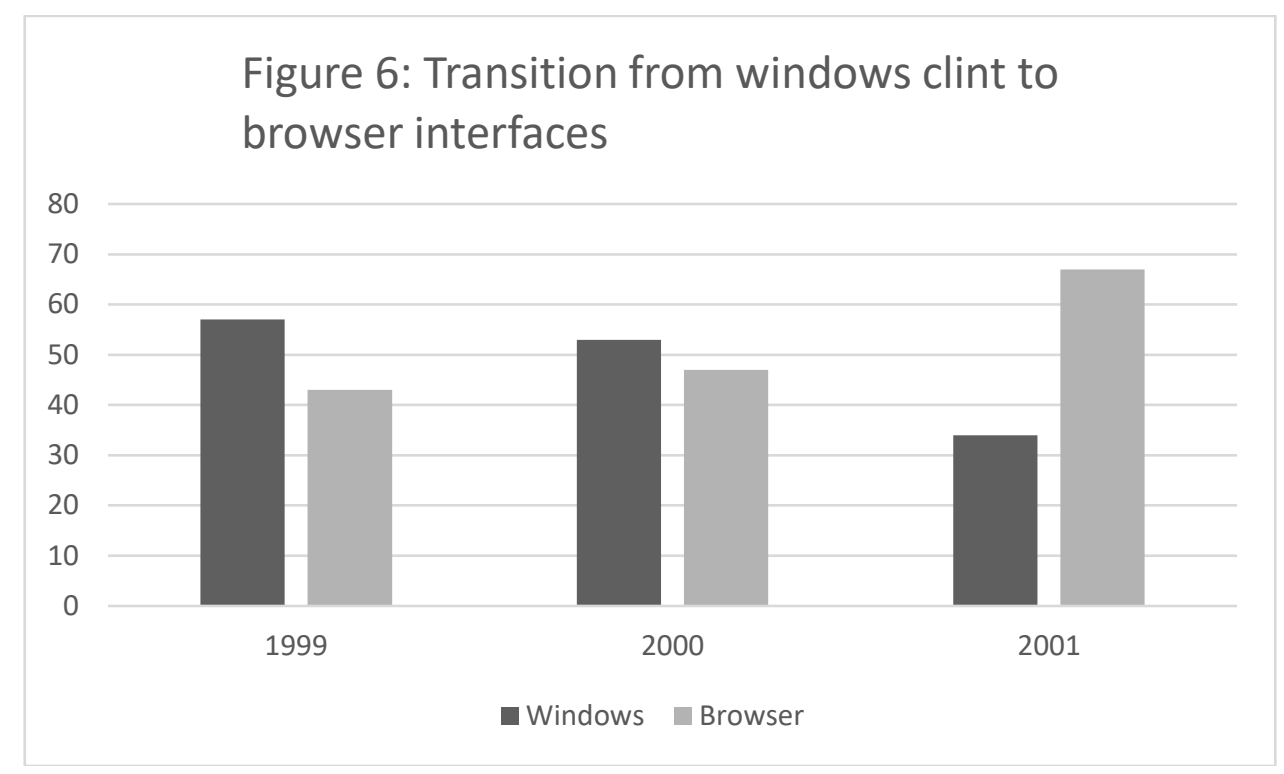

A broader shift is also clear away from traditional print resources. In 1998 when the question was first asked on average $55 \%$ of resource budgets of those information services included in the survey were spent on print resources, and $45 \%$ on digital. That figure changed only gradually over the coming years (Figure, 7 ) leading the survey to comment:

The results suggest that the migration to electronic data might now have peaked - that the current mix of spending on paper and electronic resources is the shape of spending in the New Information Economy (Smith: 2001: 21).

Unfortunately this prediction proved rash; by 2004 on average $62 \%$ of resource budgets in participant information services were being spent on digital resources (Foster \& Foster, 2004). Nevertheless the survey did reveal that migration to electronic resources occurred at different rates in different sectors, with the corporate sector leading the way (Foster \& Foster, 2002). Although the distribution of print and digital was not tracked in the same way in subsequent years the trend can be seen to continue progressively in the coming years. By 2006 "The great majority of our corporate respondents are committing upwards of 80 per cent of their budgets on electronic material" (Foster \& Foster, 2006). After this time with the transition to digital more or less complete in the corporate sector to where the focus of the survey has shifted, the question is not asked in direct form again.

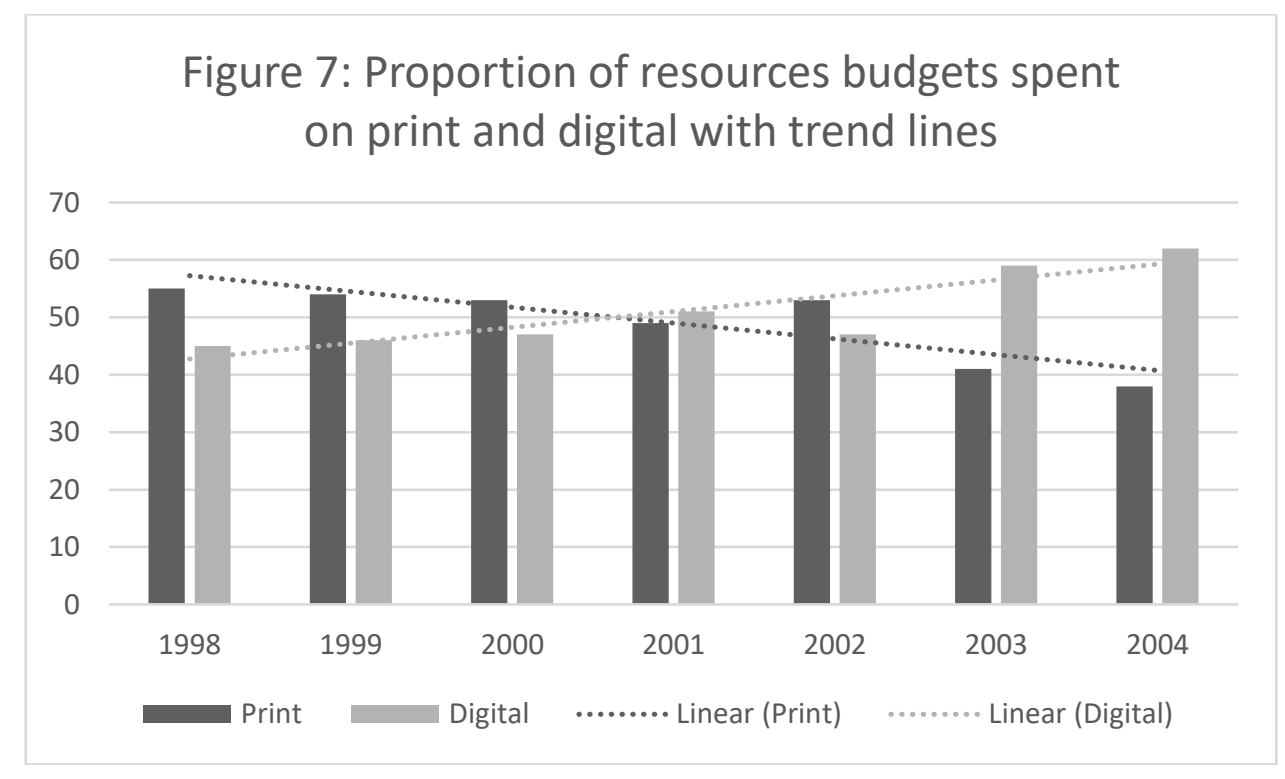


The transition from print to digital business information is evident much earlier in the surveys through other data that is collected, but this largely goes unrecognised at the time. In its second year for example the survey picked-up "a significant migration away from traditional sources of UK company financial data, in favour of online and CD-ROM products" (Headland Press, 1992: 4). The question of timeliness and accuracy of business information was raised the same year, with the survey noting:

Printed directories are the medium most likely to contain data which our respondents regard as inaccurate. It's reasonable to assume that most of the inaccurate data is, in fact, out-ofdate - by their nature, directories date rapidly, especially in a fast-changing economy (Headland Press, 1992: 10).

The trend for increasingly accurate information is explicitly attributed by the survey to the timeliness of emerging digital resources. Indeed by 1995 a significant minority of respondents had stopped subscribing to print newspapers, inviting the observation that "our survey is probably the first indicator that Fleet Street's worst fears are justified: the daily newspaper is, indeed, under threat from electronic substitutes" (Headland Business Information, 1995a: 6). It may well indeed have been. Either way the inexorable transition from print to digital now obvious to us echoes largely unheard throughout the surveys until it was almost complete. It is only in retrospect that the patterns of technological change become clear.

\subsection{Theme 4: The impact of digital technologies on information work}

The inexorable digitisation of business information resources, products and services has had a profound effect on the nature of information work over the period of the survey. This is perhaps the most significant trend revealed by the surveys. Many aspects of this will be discussed in more detail in the second part of this review published in the next issue of Business Information Review, however it is appropriate to cover some parts of this shift here where they explicitly relate to technological change. Because these changes have generally been evolutionary, rather than revolutionary, it is easier to overlook the long term trends in the profession. The value of the BIR Annual survey arises in part because of the way in which it reveals these long-term trends.

In summary terms the trends can be presented as follows:

- There has been an inexorable move to delivery of information product and services on enduser desktops. While aspects of this are evident throughout the surveys (particularly with networked products discussed in Smith $(1991 ; 1992 ; 1993)$, the trend is exacerbated after the more general rise of the World Wide Web in the late 1990s. In 1997 the survey reported that "there is little evidence of penetration of end-user online services in the organizations employing our business librarian respondents" (Smith, 1997: 1). The following year it reported that "the Internet is reaching end-user desktops to an extent that CD ROM and Online haven't been able to manage" (Smith, 1998: 11). From around 2000 the surveys reveal an increasing migration of information products and services to end-user desktops, particularly associated with a more user-friendly conception of Web enabled databases. For example in 2001 the survey reported that "although end-users proved resistant to propriety dial-up online information services, we consider that users are readier to embrace Web-based information" and attributes this to the perception that they are 'simpler to use"' (Smith, 2001: 7)

- The migration of products and services has meant that the kinds of routine enquiries and research that were the mainstay of business information work in the 1990s declined over time. End-users within corporations became more likely to undertake basic company and market research themselves.

- The threat of this to the information profession was a fundamental concern of the 1990s and early 2000s, and frequently discussed by the surveys. However, rather than undermining the role of business information professionals the migration to end-user access had a number of positive outcomes. Firstly, there was an increase in time spent on more complex (and arguably fulfilling) research, at the expense of routine enquiries. As a consequence the status 
of business information professionals grew, because their work became increasingly recognised as an expertise in its own right. Finally, information professionals responded to this by increasingly "adding value" to the work that they undertake.

- Finally, the work of business information professionals has tended to diversify in interesting ways. From the late 1990s onwards there is a growing role in training within organisations. Over time the surveys reveal increased roles in strategic management, particularly in relation to information policies, information and data security, knowledge management and related areas.

The BIR Annual survey captured these trends as they took place; indeed one of the most interesting insights from the surveys is its prediction in 1999 of forthcoming changes to information work:

The way forward for librarians, in our view, is to extend their skills base by adding the ability to analyse and interpret business data, turning it into actionable intelligence. This suggestion usually meets blank incomprehension when it is raised. (Smith, 1999: 13)

One of the recurring themes in the surveys from the early 2000 s onwards is the idea of information departments rising up the value-chain within organisation (e.g. Foster, 2007; 2013). There is an increased focus in not only providing access to information and resources, but on adding value to information, undertaking complex business research, and directly contributing to income generation.

Between 1998 and 2001 the survey tracked the perceived future impact of end-user access to information work. At the beginning of this period over $70 \%$ of respondents thought end-user access would likely change the nature of demands on business information centres and libraries, rather than increase demand (12\%), have no effect on demand (12\%) or reduce demand (4\%) (Smith, 1998). By the end of the period over $80 \%$ of respondents believed the nature of demand would be changed, and only 3\% believed it would reduce demand (Smith, 2001). From 2002 the survey began to track not the perceived future impact, but the perceived current impact. Over this time there is a decline in respondents who feel end-user access is changing the nature of the demand, but this is likely to reflect changes that have already taken place over the preceding decade in the nature of information work (figure: 7).

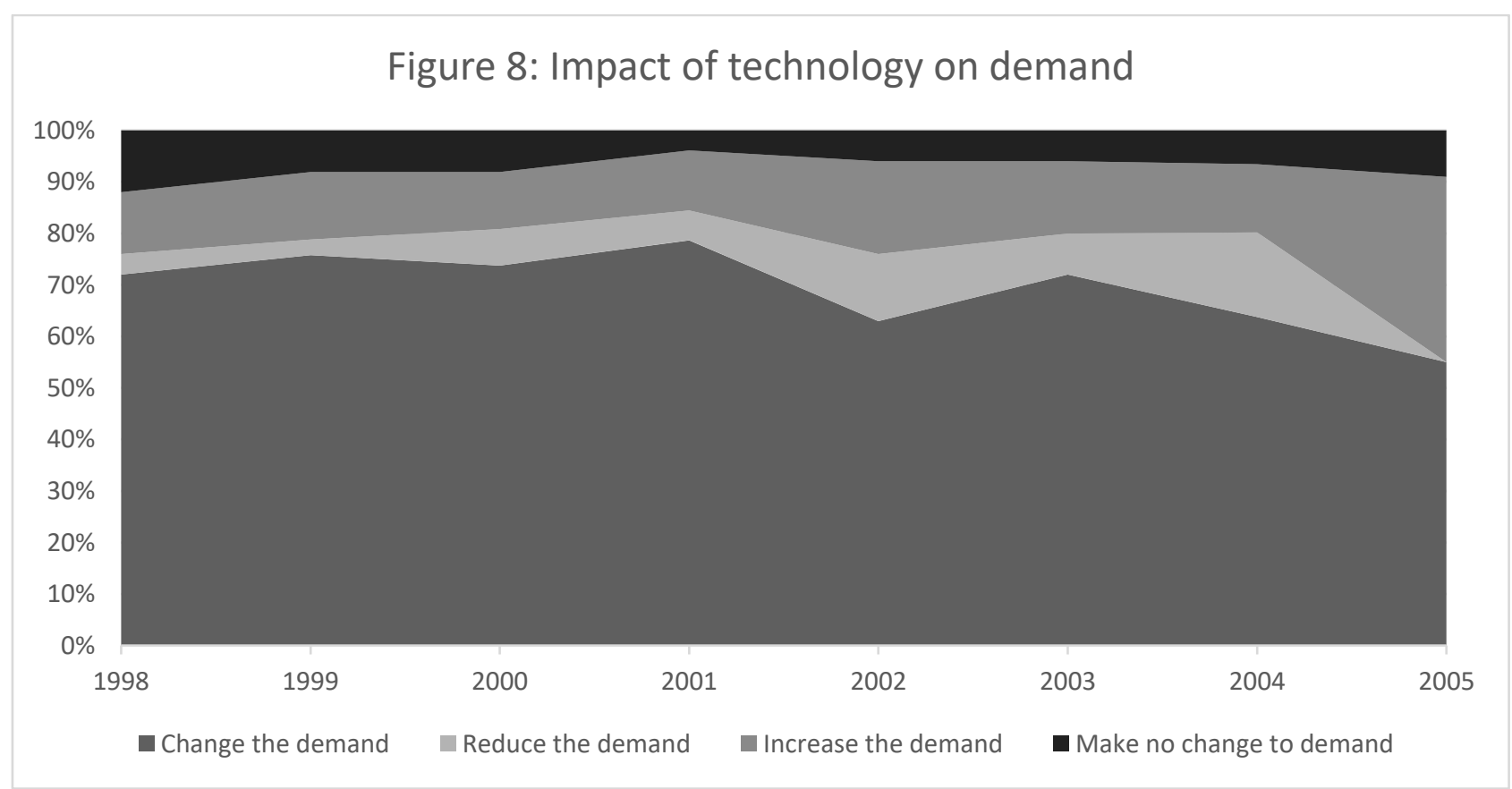


One of the interesting aspects of this is that the survey reveals a consistent optimism about the impact of technology on business information work. This optimism is also paralleled in the qualitative data gathered by the surveys. A brief selection of the comments on the changes to information work throughout this period is presented in Table 1 below; this is edited down from the vast numbers of comments on this issue published in the surveys. Nevertheless even in this form it makes very clear the way that technology tended to create new roles and functions rather than simply replacing existing ones.

\begin{tabular}{|c|c|}
\hline Year & Comments \\
\hline 1998 & $\begin{array}{l}\text { - Frees department to provide customized, focused services; } \\
\text { - Information service will have to [...] offer more tailored services; } \\
\text { - } \quad \text { More value-added information. }\end{array}$ \\
\hline 1999 & $\begin{array}{l}\text { Basic searching will be done by end-users, while in-depth, detailed research } \\
\text { and analysis will be done by Information Department; } \\
\text { - We will train end-users - the overall effect of increased access for end- } \\
\text { users will raise the profile of the information department's services; } \\
\text { - We believe the change will be towards more in-depth research. }\end{array}$ \\
\hline 2000 & $\begin{array}{l}\text { - We act as facilitators, pushing information out to the users; more end-user } \\
\text { access requires more training; } \\
\text { Department focusing more on self-help with customers having access to } \\
\text { online services which are broad-based rather than specific; more advice on } \\
\text { searching etc. }\end{array}$ \\
\hline 2001 & $\begin{array}{l}\text { - We do more in-depth searches now and fewer basic ones; } \\
\text { - Library role is more that of a facilitator than a provider of information; } \\
\text { - Empowering the user leads to more interesting information work; } \\
\text { - } \quad \text { Makes for more in-depth/value-added queries; } \\
\text { - Fewer but more complex enquiries. }\end{array}$ \\
\hline 2002 & $\begin{array}{l}\text { - library seen as expert searchers and training capability; } \\
\text { - More difficult research comes to the information department; } \\
\text { - Demand is for more in-depth research work and analysis as users can help } \\
\text { themselves to simple information available on the Internet; } \\
\text { - Number of requests has decreased but they have increased in their } \\
\text { complexity. }\end{array}$ \\
\hline 2003 & $\begin{array}{l}\text { - The enquiries that come through tend to be more in-depth (and more } \\
\text { interesting); } \\
\text { - More advice; more spin-off projects; more substantial, large-scale projects. } \\
\text { - Information Service still doing desktop level for some departments but } \\
\text { overall now perceived more as use for value add. }\end{array}$ \\
\hline 2004 & $\begin{array}{l}\text { - Users find answers to easy questions on the web and come to us with more } \\
\text { complex searches }\end{array}$ \\
\hline
\end{tabular}

Table 1: qualitative comments on the impact of technology

There is an interesting parallel with the fate of the information profession in the face of new technologies, such as Artificial Intelligence (AI); the fact that technology has tended to change the nature of professional roles rather than simply replace them is perhaps heartening. 
One way in which technology has changed business information work is by providing opportunities for business information professionals to become take on organisation-wide responsibilities. A typical example of this in the 1990s was the involvement of information professionals in corporate intranets. Intranets per se have now blended into the general fabric of information technology within corporations and organisations, but in the mid nineteen-nineties they were heralded by many as a revolutionary technology to bring about substantial business benefits and to help change the culture of commercial organisations. Nevertheless the apparent lack of involvement of information professionals in intranet management revealed by the surveys is perhaps surprising.

The first time the question is asked in in 1997 only $23 \%$ of respondents made any use of a corporate intranet, and one respondent commented "intranet - what's this?" (Smith, 1997: 6). The survey commented:

If you were to believe everything that you read in the computer press at the moment, you would think that Intranet was already the major Net application. The fact that only a small minority of out high-tech librarian respondents are currently using Intranets is an indication that the application has so far reached only fairly low penetration. (Smith, 1997)

The following ten years show gradual greater use of intranets within corporations. Over time almost all information professionals responding to the survey state some involvement in creating content or managing aspects of intranet implementation. But there is another side to this story. It is clear from responses into the 2000 s that far from being a mature technology, intranets are still very much under development, and much of the content is of relatively low value. In 2004 for instance the survey notes that "across all sectors, descriptions of library/information services are the most commonly provided" (Foster \& Foster, 2004); this remains true until 2006 (Foster \& Foster, 2006).

From 2007 the focus of the survey changes to richer qualitative responses, but as these relate to intranets they tell a similar story:

- Beef up intranet: develop (Foster, 2007)

- Improve quality, appearance and structure of intranet (Foster, 2007)

- improve intranet content, use of social technologies and encourage collaboration (Foster, 2008)

- Re-vamp intranet; improve content management system (Foster, 2009)

- We need to have a better search engine on our intranet site (Foster, 2010).

These hardly testify to a ringing endorsement. The impact of intranets settles down into the 2010s; from then comments more often relate to the ways in which intranets are being used, rather than the ways in which they need to be improved and developed. By this stage they have perhaps found their own level, and distinctive uses that are more modest than initially hoped, but nevertheless of real business value. This reaffirms the pattern of initially patchy and slow adoption, before a technology that promised wide application finds value in more niche functions.

Equally interesting is the relatively low level of control over intranet development exerted by business information professionals throughout the period. While contributing content to intranets is very common and become almost universal, involvement in managing the intranet itself generally lies outside the library or information centre. Throughout the period the number of business libraries and information services that state they have significant involvement in managing the corporate intranet remains a small minority.

There is a similar story with respect to knowledge management (KM) which through this period was closely associated in many people's minds with intranets and other technological solutions. Indeed the survey itself assumes for some years after the question is first asked in 1998 that KM is synonymous with a KM System (Smith, 1998). In $1998 \mathrm{KM}$ is "is still a minority activity for both business librarians and their parent companies" (Smith, 1998). A year later "only a tiny number of librarians have been involved in KM development, contribute content or have witnessed changes in their jobs as a result of KM systems" (Smith, 1999). Interest in KM appears to peak initially around 
2002 (Foster \& Foster, 2002), and in subsequent surveys there is a notable decline in the number of respondents who state their organisations have KM strategies. For the most part in this period where business information professionals are involved in knowledge management, it is for the most part a matter of incorporating their existing role within a wider KM strategy. There are few examples from this period where business information professionals are leading KM initiatives within organisations by the report.

However this changes notably from 2013, where there is both a renewed interest in knowledge management in general revealed by the survey, and more direct involvement of information professionals in knowledge management within corporate contexts (Foster, 2013). In part this resurgence of $\mathrm{KM}$ arises from the rise of social media technologies in the mid 2000s, discussed below.

\section{Theme 6: Newer technologies}

In more recent years the surveys have addressed a range of emerging technologies from social media tools such as blogs and wikis, to Artificial Intelligence and Blockchains. This begins with the emergence of web 2.0 and social media in 2006, which begin to make an impact on the surveys from 2007 (e.g. Foster, 2007). At that stage there is some interest in social media tools, but not much actual activity evident within respondents to the survey. The pattern of development more or less maps that for the Internet a decade earlier; by 2008 there is no real increase in activity, but a significant increase in interest, planning and thinking around the opportunities (Foster, 2008). The survey notes over a number of years a patter of a third of respondants who are true believers in social media, a third who are agnostic, and a third who remain atheists (e.g. Foster, 2009; 2010). From about 2013 there is an increase in the use of social media within a corporate context, particularly as it is tied to renewed interest in Knowledge Management programmes (Foster, 2013). However there remains significant scepticism towards the business value of social media technologies, while at the same time considerable enthusiasm for personal use of social networking, blogging, and microblogging.

Mobile technologies (mobile phones, PDAs, tablet computers) first emerge in a comment in 2006, and for the next four years appears in occasional responses from participant (e.g. Foster, 2006; 2007). From 2010 the survey begins to ask about the use of mobile technologies directly (Foster, 2010). By this time mobile technologies had already had a significant impact on corporate work practices, however there was little evidence of business information services and business libraries making significant use of mobile technologies for the delivery of business information (Foster, 2010: 21). The following year there is still a lukewarm interest in mobile technologies, with the survey reporting "neither vendors nor information managers can afford to run headlong into mobile offerings without a clear picture of how mobile content fits into workflow" (Foster, 2011: 21). From this point onwards there is a clear and consistent adaptation to mobile technologies, particularly for the delivery of information to end users, however this is largely in line with wide corporate trends and information vendor services. There is less evidence of business information professionals innovating in this area.

Information security, data security and cybersecurity emerge as more significant concerns of information professionals from around 2015 (Foster, 2015). Prior to this time these issues when mentioned are predominantly related to organisational IT functions. However from 2015 is becomes clear that information professionals are taking a more direct role in information policy and strategy in general within organisations, including contributing or sometimes leading security issues. A cluster of other concerns begin to emerge at this time including big data and data protection.

The most recent technological innovation to make an impact in the surveys has been Artificial Intelligence (Al). The 2018 survey in particular reveals the extent to which $\mathrm{Al}$ applications are beginning to impact on information work, from chatbots to intelligent search. However the survey also revealed scepticism about the impact of Al. Much like the case with the Internet and World Wide Web in the mid-nineties, is appears that the sector may be on the brink of significant changes, but at the moment the use of $\mathrm{Al}$ is relatively patchy. 


\section{General observations:}

This brief review has addressed some of the technological themes that have emerged in the BIR Annual Survey between 1991 and 2018. In this section we will now turn to explore some of the general trends that emerge in the survey about the ways in which technological change occurs, and how it impacts upon professional work. This draws on the discussion above, but also draws on the key technological findings of the surveys which are summarised in Appendix 3.

One of the clearest themes that emerges through all the surveys is a lag between the introduction of new technology and its wider adoption in the business information sector. Information professionals often have a self-image as early adopters of new technologies. This idea is repeatedly stated throughout the surveys (e.g. Smith, 1997: 6), and there is some evidence to suggest that business information professionals are on the cutting-edge of technological change. The Internet and World Wide Web were addressed by the BIR Annual Surveys years before they had penetrated the consumer market; Web 2.0 was a topic in the surveys within two years of the term being coined, and Al has featured in the surveys in parallel with wider cultural awareness.

However, the truth is more complex. The information profession may be on the cutting edge of debates about the emergence of new technology, but widespread adoption inevitably lags behind, at least in the corporate sector - and the surveys through the 1990s and early 2000 s imply corporate information centres are often ahead of public, academic and governmental sectors. One of the key outcomes from reviewing the surveys is that the information profession in much slower at adopting new technologies than perhaps it believes itself to be, and that adoption when it takes place it patchier than the professional literature might imply.

In 1971 Everett Rogers published Diffusions of Innovations, a work which set out the ways in which technological change happens. That work differentiated five categories adoption of innovation:

1. Innovators: bring about change within the organisation.

2. Early adopters: high degree of opinion leadership; ahead of the vast majority.

3. Early Majority: lagging behind early adopters but ahead of the majority.

4. Late Majority: greet innovation with significant scepticism but adopt innovation when its benefits are proven.

5. Laggards: tend to be focussed on traditional practices and resist change (Rogers \& Shoemaker, 1971).

Throughout the surveys there is ample evidence of individuals who fall into each of these categories. Deep scepticism is evident about all of the technological innovations discussed in this review, from CD ROM through to Social Media and Al. There are also many examples of information professionals and information centres that are innovating in their use of technology. However, the clear finding from this review is that the general reaction to technological innovation of information professionals and information centres in the corporate sector falls comfortably into the early majority category, standing back from innovation for long enough to establish its benefits but beating most of the crowd. In most cases this is probably the right place to be. There are benefits to early adoption but there are also significant risks, and in the roles that information professionals usually play within corporate organisations the risks will generally outweigh the benefits. That is to say that in corporate contexts in particular, it is obvious that emerging technologies need to prove their value before they are more widely adopted, and even then adoption is often staged.

There are a number of reasons for this of course. A technology is of little use to business information professionals unless it already has sufficient critical mass to ensure the uses that can be made of that technology are beneficial to the organisation. That is to say that network technology in particular is often accompanied by network effects that tie the value of participation to the rates of participation. Innovation in business information services is rarely a business critical issue. Secondly the value of adoption has to be significant enough to overcome the inertia of change - of learning new ways of 
doing things and adapting to new work habits and practices. Finally the position of information centres and information professional within the corporate sector has often been in the past to support business professes, rather than lead them.

The surveys also reveal the ways in which the transformational nature of technological innovation is often overlooked at the time that it is taking place. Through the first two years of the survey the predominant concern about the impact of technology is its disruption of traditional print services, and the information vendor market. For example, the first survey noted that "online databases have made a serious impact on the viability of printed indexing services, to the extent that their future may be less certain than it once was (BIR, 1991); they are in fact never mentioned again. Similarly a year later the following observation appears in the survey:

The very fact that an electronic service is available, enabling the occasional potential user to draw on information as required, has probably led some to cancel subscriptions to print products, secure in the knowledge that the data is available if required, at a much lower price than having to buy the whole collection speculatively in print format. Some information providers may, therefore, have suffered from the availability of online data: subscribers stop buying the print product, and only make limited use of the online equivalent. (Headland press, 1992)

There is rather less recognition at this stage of the challenge digital resources pose for the information profession itself. Digital information is not seen as a challenge to the ways in which information work is done, but rather simply a new format in which business information is delivered analogous to traditional resources but different in quality or kind. This is occasionally framed as both challenge for and solution to the quality of business information (particularly: Headland Press, 1992). The broader implications or technological change tend to be recognised retrospectively.

With hindsight it is easy to recognise the transformational and disruptive influence of the Internet and World Wide Web both on information vendors and information professionals; it is of course a transformation that is still underway. Nevertheless this was also largely overlooked by the surveys until it had already largely happened. This suggests some interesting reflections on the ways in which we experience technological change in the workplace that perhaps have relevance for newer innovations. Clay Shirky has written that:

Most professions exist because there is a scarcity that requires ongoing management... A profession becomes, for its members, a way of understanding the world. Professionals see the world through a lens created by other members of their profession ... Sometimes, though, the professional outlook becomes a disadvantage, preventing the very people who have most at stake - the professionals themselves - from understanding major changes to the structure of their profession. (Shirky, 2009: 57-59)

When something truly transformational comes along, it is easy to see that transformation through the prism of existing habits, professional practices, and ways of doing things. The Internet and World Wide Web look perhaps like another set of tools for accomplishing existing goals competing with existing tools that may complete those tasks more or less well. It is harder perhaps to recognise that the change may render old goals obsolete, and create new goals that could not have previously existed. Two decades later we have adjusted to the new contexts for information work, and it is easy to forget the nature of the change that has taken place. The BIR Annual Surveys capture a technological change in process, but captures also only that part of the change about which the profession was generally aware. It is not until the World Wide Web is universally available that the surveys begin to reflect on the more fundamental changes to information work that the new context implies (see section 3 below). The same is perhaps true of current technological innovations such as $\mathrm{Al}$ : it is easy to understand how they might replace or complement existing tools or even professional roles in accomplishing exiting tasks; it is harder to predict how they might transform the kinds of tasks that we wish to accomplish. That kind of change only emerges in retrospect. 


\section{Appendix 1: overview of BIR Annual Survey}

The following table provides an overview of the publication record of the BIR Annual Survey.

\begin{tabular}{|c|c|c|c|c|c|c|}
\hline Survey & No. & Date published & \begin{tabular}{|l}
$\begin{array}{l}\text { Volume } \\
\text { (issue) }\end{array}$ \\
\end{tabular} & Names Author & Methodology & Pages \\
\hline 1991 & 1 & July 1991 & $8(1)$ & Headland Press & $\begin{array}{l}\text { General postal } \\
\text { questionnaire }\end{array}$ & 11 \\
\hline 1992 & 2 & July 1992 & $9(1)$ & Headland Press & $\begin{array}{l}\text { General postal } \\
\text { questionnaire }\end{array}$ & 11 \\
\hline 1993 & 3 & October 1993 & $10(2)$ & Headland Press & $\begin{array}{l}\text { General postal } \\
\text { questionnaire }\end{array}$ & 12 \\
\hline 1994 & 4 & January 1995 & $11(3)$ & $\begin{array}{l}\text { Headland Business } \\
\text { Information }\end{array}$ & $\begin{array}{l}\text { General postal } \\
\text { questionnaire }\end{array}$ & 14 \\
\hline 1995 & 5 & October 1995 & $12(2)$ & $\begin{array}{l}\text { Headland Business } \\
\text { Information }\end{array}$ & $\begin{array}{l}\text { General postal } \\
\text { questionnaire }\end{array}$ & 27 \\
\hline 1997 & 6 & March 1997 & $14(1)$ & Gerry Smith & $\begin{array}{l}\text { General postal } \\
\text { questionnaire }\end{array}$ & 14 \\
\hline 1998 & 7 & March 1998 & $15(1)$ & Gerry Smith & $\begin{array}{l}\text { General postal } \\
\text { questionnaire }\end{array}$ & 17 \\
\hline 1999 & 8 & March 1999 & $16(1)$ & Gerry Smith & $\begin{array}{l}\text { General postal } \\
\text { questionnaire }\end{array}$ & 19 \\
\hline 2000 & 9 & March 2000 & $17(1)$ & Gerry Smith & $\begin{array}{l}\text { General postal } \\
\text { questionnaire }\end{array}$ & 17 \\
\hline 2001 & 10 & March 2001 & $18(1)$ & Gerry Smith & $\begin{array}{l}\text { General postal } \\
\text { questionnaire }\end{array}$ & 19 \\
\hline 2002 & 11 & March 2002 & $19(1)$ & $\begin{array}{l}\text { Allan Foster \& Pam } \\
\text { Foster }\end{array}$ & $\begin{array}{l}\text { General postal } \\
\text { questionnaire }\end{array}$ & 18 \\
\hline 2003 & 12 & March 2003 & $20(1)$ & $\begin{array}{l}\text { Allan Foster \& Pam } \\
\text { Foster }\end{array}$ & $\begin{array}{l}\text { General postal and } \\
\text { electronic } \\
\text { questionnaire }\end{array}$ & 20 \\
\hline 2004 & 13 & March 2004 & $21(1)$ & $\begin{array}{l}\text { Pam Foster \& Allan } \\
\text { Foster }\end{array}$ & $\begin{array}{l}\text { General postal and } \\
\text { electronic } \\
\text { questionnaire }\end{array}$ & 23 \\
\hline 2005 & 14 & March 2005 & $22(1)$ & $\begin{array}{l}\text { Pam Foster \& Allan } \\
\text { Foster }\end{array}$ & $\begin{array}{l}\text { Targeted and } \\
\text { general postal and } \\
\text { electronic } \\
\text { questionnaire }\end{array}$ & 23 \\
\hline 2006 & 15 & June 2006 & $23(2)$ & $\begin{array}{l}\text { Pam Foster \& Allan } \\
\text { Foster }\end{array}$ & $\begin{array}{l}\text { Targeted and } \\
\text { general postal and } \\
\text { electronic } \\
\text { questionnaire }\end{array}$ & 25 \\
\hline 2007 & 16 & March 2007 & $24(1)$ & Allan Foster & $\begin{array}{l}\text { Targeted } \\
\text { interviews }\end{array}$ & 17 \\
\hline 2008 & 17 & March 2008 & $25(1)$ & Allan Foster & $\begin{array}{l}\text { Targeted } \\
\text { interviews }\end{array}$ & 19 \\
\hline 2009 & 18 & March 2009 & $26(1)$ & Allan Foster & $\begin{array}{l}\text { Targeted } \\
\text { interviews }\end{array}$ & 18 \\
\hline 2010 & 19 & March 2010 & $27(1)$ & Allan Foster & $\begin{array}{l}\text { Targeted } \\
\text { interviews }\end{array}$ & 19 \\
\hline 2011 & 20 & March 2011 & $28(1)$ & Allan Foster & $\begin{array}{l}\text { Targeted } \\
\text { interviews }\end{array}$ & 17 \\
\hline
\end{tabular}




\begin{tabular}{|l|l|l|l|l|l|l|}
\hline 2012 & 21 & March 2012 & $29(1)$ & Allan Foster & $\begin{array}{l}\text { Targeted } \\
\text { interviews }\end{array}$ & 20 \\
\hline 2013 & 22 & March 2013 & $30(1)$ & Allan Foster & $\begin{array}{l}\text { Targeted } \\
\text { interviews }\end{array}$ & 19 \\
\hline 2014 & 23 & March 2014 & $31(1)$ & Allan Foster & $\begin{array}{l}\text { Targeted } \\
\text { interviews }\end{array}$ & 27 \\
\hline 2015 & 24 & March 2015 & $32(1)$ & Allan Foster & $\begin{array}{l}\text { Targeted } \\
\text { interviews }\end{array}$ & 28 \\
\hline 2016 & 25 & March 2016 & $33(1)$ & Denise Carter & $\begin{array}{l}\text { Targeted } \\
\text { interviews }\end{array}$ & 10 \\
\hline 2017 & 26 & $\begin{array}{l}\text { September } \\
2017\end{array}$ & $34(3)$ & Denise Carter & $\begin{array}{l}\text { Targeted } \\
\text { interviews and } \\
\text { general } \\
\text { questionnaire }\end{array}$ & 16 \\
\hline 2018 & 27 & $\begin{array}{l}\text { September } \\
2018\end{array}$ & $35(3)$ & Denise Carter` & $\begin{array}{l}\text { Targeted } \\
\text { interviews and } \\
\text { general } \\
\text { questionnaire }\end{array}$ & 17 \\
\hline
\end{tabular}

\section{Appendix 2: Content analysis of key technologies}

The table below shows the frequency over time of key technologies referenced in the surveys;

Figure 9 below represents this data proportionately.

\begin{tabular}{|c|c|c|c|c|c|c|c|}
\hline Year & Online & CD ROM & FAX & Internet & email & Web & Intranet \\
\hline $\mathbf{1 9 9 1}$ & 17 & 13 & 0 & 0 & 0 & 0 & 0 \\
\hline $\mathbf{1 9 9 2}$ & 14 & 25 & 0 & 0 & 0 & 0 & 0 \\
\hline $\mathbf{1 9 9 3}$ & 19 & 37 & 10 & 5 & 0 & 0 & 0 \\
\hline $\mathbf{1 9 9 4}$ & 12 & 31 & 10 & 11 & 2 & 0 & 0 \\
\hline $\mathbf{1 9 9 5}$ & 28 & 41 & 0 & 19 & 4 & 0 & 0 \\
\hline $\mathbf{1 9 9 7}$ & 32 & 23 & 0 & 48 & 4 & 23 & 6 \\
\hline $\mathbf{1 9 9 8}$ & 38 & 13 & 0 & 35 & 5 & 39 & 7 \\
\hline $\mathbf{1 9 9 9}$ & 53 & 11 & 6 & 52 & 10 & 36 & 8 \\
\hline $\mathbf{2 0 0 0}$ & 60 & 10 & 1 & 62 & 20 & 52 & 11 \\
\hline $\mathbf{2 0 0 1}$ & 67 & 7 & 1 & 32 & 15 & 56 & 11 \\
\hline $\mathbf{2 0 0 2}$ & 12 & 3 & 1 & 16 & 2 & 31 & 21 \\
\hline $\mathbf{2 0 0 3}$ & 10 & 4 & 0 & 7 & 2 & 14 & 17 \\
\hline $\mathbf{2 0 0 4}$ & 12 & 0 & 0 & 0 & 10 & 12 & 15 \\
\hline $\mathbf{2 0 0 5}$ & 8 & 0 & 0 & 1 & 0 & 7 & 12 \\
\hline $\mathbf{2 0 0 6}$ & 10 & 4 & 0 & 0 & 0 & 24 & 15 \\
\hline $\mathbf{2 0 0 7}$ & 3 & 0 & 0 & 1 & 0 & 11 & 5 \\
\hline $\mathbf{2 0 0 8}$ & 4 & 0 & 0 & 0 & 0 & 31 & 13 \\
\hline $\mathbf{2 0 0 9}$ & 6 & 0 & 0 & 0 & 0 & 5 & 1 \\
\hline $\mathbf{2 0 1 0}$ & 3 & 0 & 0 & 0 & 2 & 5 & 5 \\
\hline $\mathbf{2 0 1 1}$ & 0 & 0 & 0 & 3 & 1 & 4 & 3 \\
\hline $\mathbf{2 0 1 2}$ & 0 & 0 & 0 & 0 & 1 & 5 & 10 \\
\hline $\mathbf{2 0 1 3}$ & 2 & 0 & 0 & 0 & 2 & 5 & 6 \\
\hline $\mathbf{2 0 1 4}$ & 3 & 0 & 0 & 0 & 7 & 5 & 7 \\
\hline $\mathbf{2 0 1 5}$ & 5 & 0 & 0 & 3 & 3 & 18 & 12 \\
\hline $\mathbf{2 0 1 6}$ & 0 & 0 & 0 & 0 & 1 & 3 & 0 \\
\hline
\end{tabular}




\begin{tabular}{|c|c|c|c|c|c|c|c|}
\hline 2017 & 1 & 0 & 0 & 0 & 3 & 8 & 3 \\
\hline 2018 & 1 & 0 & 0 & 7 & 1 & 8 & 0 \\
\hline Totals & 480 & 222 & 29 & 302 & 95 & 402 & 188 \\
\hline Year & $\begin{array}{l}\text { social } \\
\text { media }\end{array}$ & wiki & $\begin{array}{c}\text { Info } \\
\text { overload }\end{array}$ & tablet & $\begin{array}{l}\text { smartph } \\
\text { one }\end{array}$ & big data & Al \\
\hline 1991 & 0 & 0 & 0 & 0 & 0 & 0 & 0 \\
\hline 1992 & 0 & 0 & 0 & 0 & 0 & 0 & 0 \\
\hline 1993 & 0 & 0 & 0 & 0 & 0 & 0 & 0 \\
\hline 1994 & 0 & 0 & 0 & 0 & 0 & 0 & 0 \\
\hline 1995 & 0 & 0 & 0 & 0 & 0 & 0 & 0 \\
\hline 1997 & 0 & 0 & 0 & 0 & 0 & 0 & 0 \\
\hline 1998 & 0 & 0 & 0 & 0 & 0 & 0 & 0 \\
\hline 1999 & 0 & 0 & 6 & 0 & 0 & 0 & 0 \\
\hline 2000 & 0 & 0 & 1 & 0 & 0 & 0 & 0 \\
\hline 2001 & 0 & 0 & 2 & 0 & 0 & 0 & 0 \\
\hline 2002 & 0 & 0 & 0 & 0 & 0 & 0 & 0 \\
\hline 2003 & 0 & 0 & 0 & 0 & 0 & 0 & 0 \\
\hline 2004 & 0 & 0 & 0 & 0 & 0 & 0 & 0 \\
\hline 2005 & 0 & 0 & 0 & 0 & 0 & 0 & 0 \\
\hline 2006 & 0 & 0 & 0 & 0 & 0 & 0 & 0 \\
\hline 2007 & 13 & 8 & 0 & 0 & 0 & 0 & 0 \\
\hline 2008 & 16 & 7 & 0 & 0 & 0 & 0 & 0 \\
\hline 2009 & 20 & 5 & 1 & 0 & 0 & 0 & 0 \\
\hline 2010 & 19 & 11 & 1 & 0 & 0 & 0 & 0 \\
\hline 2011 & 31 & 7 & 0 & 2 & 0 & 0 & 0 \\
\hline 2012 & 25 & 5 & 0 & 1 & 3 & 1 & 0 \\
\hline 2013 & 23 & 1 & 0 & 3 & 4 & 7 & 0 \\
\hline 2014 & 38 & 1 & 0 & 14 & 6 & 22 & 0 \\
\hline 2015 & 18 & 0 & 0 & 0 & 0 & 17 & 0 \\
\hline 2016 & 11 & 0 & 0 & 2 & 0 & 6 & 0 \\
\hline 2017 & 14 & 0 & 0 & 0 & 0 & 10 & 0 \\
\hline 2018 & 7 & 0 & 0 & 0 & 0 & 1 & 95 \\
\hline Totals & 235 & 45 & 11 & 22 & 13 & 64 & 95 \\
\hline
\end{tabular}




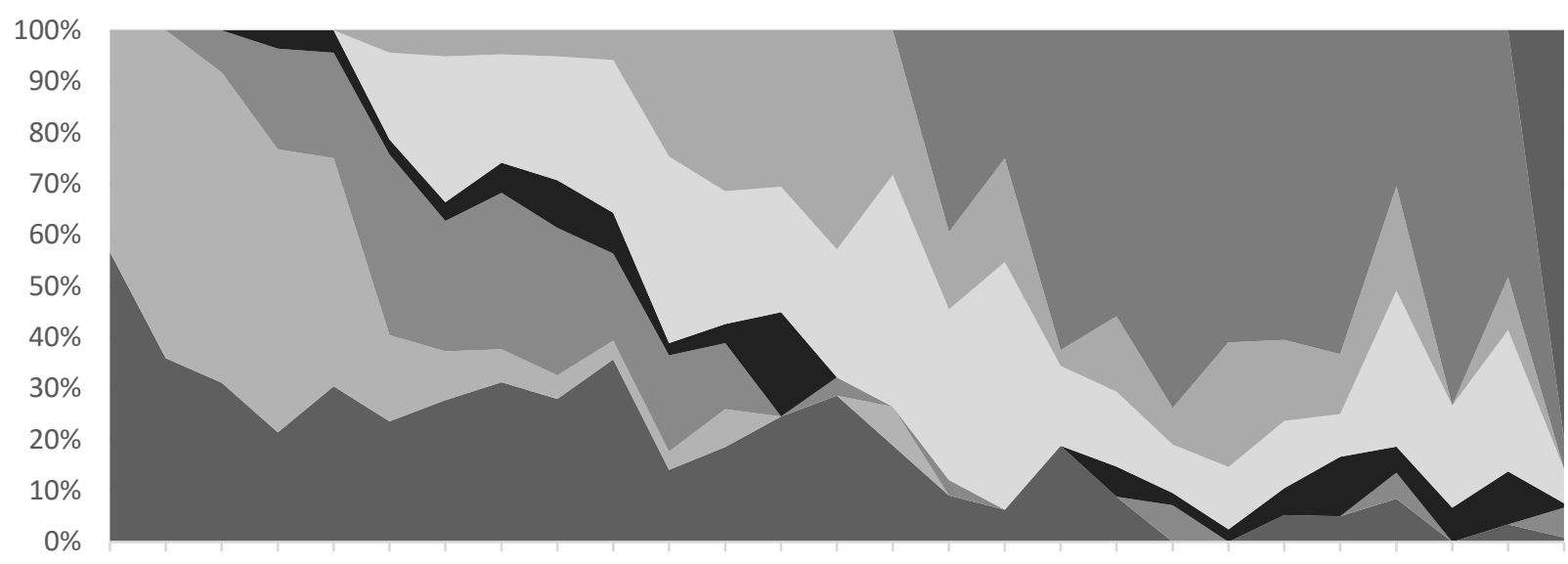

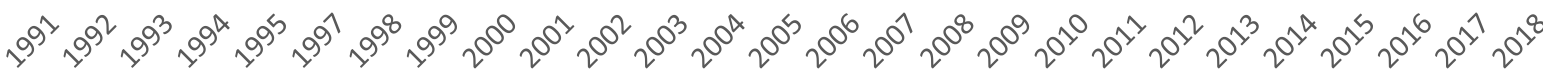

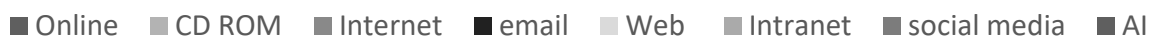

\section{Appendix 3: Key technological findings:}

The table below lists a summary the key technology-related findings from each published BIR annual survey.

\begin{tabular}{|l|l|}
\hline Survey year & Key technological findings \\
\hline 1991 & $\begin{array}{l}\text { Low usage of CD-ROM business information products (Headland Press, } \\
\text { 1991: 12). }\end{array}$ \\
\hline 1992 & $\begin{array}{l}\text { CD-ROM has made steady progress in penetrating the business library } \\
\text { market in the last twelve (Headland Press, 1992: 4). }\end{array}$ \\
& $\begin{array}{l}\text { A significant migration away from traditional sources of UK company } \\
\text { financial data, in favour of online and CD-ROM products (Headland } \\
\text { Press, 1992: 4). }\end{array}$ \\
\hline 1993 & $\begin{array}{l}\text { CD-ROM continues its steadily increasing penetration of the marketplace } \\
\text { (Headland Press, 1993: 3). }\end{array}$ \\
\hline 1994 & $\begin{array}{l}\text { The Internet has made little impact on UK business libraries so far; CD- } \\
\text { ROM has probably reached maximum penetration; and Windows is rapidly } \\
\text { developing as a major platform for searching electronic databases } \\
\text { (Headland Business Information, 1995a: 2). }\end{array}$ \\
\hline 1995 & $\begin{array}{l}\text { One third of business libraries regularly use the Internet, but use is about } \\
\text { to take off (Headland Business Information, 1995b: 3). }\end{array}$ \\
\hline 1997 & $\begin{array}{l}\text { Little evidence of penetration of end-user online services in the } \\
\text { organizations employing our business librarian respondents (Smith, 1997: } \\
\text { 1) }\end{array}$ \\
\hline 1998 & $\begin{array}{l}\text { While some end-user services - the Internet and CD-ROM - are being } \\
\text { taken up, there is little evidence of penetration of end-user online services } \\
\text { in the organizations employing our business librarian respondents. The } \\
\text { much-hyped 'push' news services, in particular, register little interest } \\
\text { (Smith, 1998: 5). } \\
\text { Business librarians now view the proliferation of end-user access to the Net } \\
\text { with equanimity. They expect the take-up of services to change the nature } \\
\text { of their work, but not to reduce their role (Smith, 1998: 5). }\end{array}$ \\
\hline
\end{tabular}




\begin{tabular}{|c|c|}
\hline & $\begin{array}{l}\text { - Business libraries have espoused the Information Age: } 50 \% \text { now spend at } \\
\text { least half their resources budgets on electronic data (Smith, 1998: 5). }\end{array}$ \\
\hline 1999 & $\begin{array}{l}\text { - The Internet has confirmed, rather than changed, the long-established } \\
\text { pattern of demand for information in UK business libraries (Smith, 1999: } \\
\text { 5) } \\
\text { - The most frequently accessed sites on the Web are those of individual } \\
\text { companies (Smith, 1999: 5). } \\
\text { - Windows interfaces are slightly more popular than browsers for database } \\
\text { searching (Smith, 1999: 5). } \\
\text { Yahoo and Alta Vista are the most popular search engines (Smith, 1999: } \\
\text { 5). } \\
\text { Knowledge management, E-commerce and online 'virtual communities' } \\
\text { have so far made little impact in the business library sector (Smith, 1999: } \\
\text { 5). }\end{array}$ \\
\hline 2000 & $\begin{array}{l}\text { - Business end-users are now clearly going online in large numbers. We } \\
\text { expect Internet penetration of UK corporate desktops to be more or less } \\
\text { complete when the Internet has become available on the desktops of } \\
\text { more than half the end-users in about } 85 \% \text { of our respondent } \\
\text { organizations: if current trends continue, that will occur in mid-2001 } \\
\text { (Smith, 2000: 5). } \\
\text { - Windows interfaces are slightly more popular than browsers for database } \\
\text { searching (Smith, 2000: 5). } \\
\text { - Alta Vista and Yahoo! are the most popular search engines (Smith, 2000: } \\
\text { 5). } \\
\text { Knowledge management and online 'virtual communities' have so far } \\
\text { made little impact in the business library sector but E-commerce is taking } \\
\text { off (Smith, 2000: } 6 \text { ). }\end{array}$ \\
\hline 2001 & $\begin{array}{l}\text { Business end-users in large companies are now online: Internet } \\
\text { penetration of UK corporate desktops is more or less complete (Smith, } \\
2001: 5 \text { ) } \\
\text { Browser interfaces are now much more popular than Windows for } \\
\text { database searching (Smith, 2001: 5). } \\
\text { - Google has supplanted AltaVista and Yahoo! as the most popular search } \\
\text { engine in this market-place (Smith, 2001: 6). } \\
\text { - More than half of respondents consider that libraries' use of online hosts } \\
\text { will eventually be replaced by direct access to information providers' Web } \\
\text { sites (Smith, 2001:6). } \\
\text { the long-term migration from print to electronic data resources might have } \\
\text { peaked (Smith, 2001:5). }\end{array}$ \\
\hline 2002 & $\begin{array}{l}\text { - The switch from print to electronic is inexorable but is slower in some } \\
\text { sectors than others (Foster \& Foster, 2002: 5). } \\
\text { - Most organizations now have intranets and the majority of business } \\
\text { libraries are making important contributions to them (Foster \& Foster, } \\
\text { 2002: 5). } \\
\text { - Google is by far the most used search engine and has doubled in } \\
\text { popularity since the last Survey (Foster \& Foster, 2002: 6). } \\
\text { Business librarians expect to contract with more electronic content } \\
\text { vendors in } 2003 \text { than in } 2001 \text { (Foster \& Foster, 2002: 6). } \\
\text { - Increased desktop electronic access is having a major effect on the } \\
\text { demands made of library/information departments (Foster \& Foster, 2002: } \\
6 \text { ). }\end{array}$ \\
\hline 2003 & $\begin{array}{l}\text { - } \quad \text { Significant move to virtual information environment in all sectors } \\
\text { - contributions to organizations' intranet and portal development continue } \\
\text { (Foster \& Foster, 2003: 5) }\end{array}$ \\
\hline
\end{tabular}




\begin{tabular}{|c|c|}
\hline 2004 & $\begin{array}{l}\text { - Tangible concern amongst academic business librarians about the need } \\
\text { for more effective marketing of quality electronic services to student and } \\
\text { staff audiences (Foster \& Foster, 2004: 14) }\end{array}$ \\
\hline 2005 & $\begin{array}{l}\text { - E-content improvement, service development and end-user training are top } \\
\text { three strategic priorities (Foster \& Foster, 2005: 15) }\end{array}$ \\
\hline 2006 & - None reported. \\
\hline 2007 & $\begin{array}{l}\text { - Social technology tools are not being used much but have great potential } \\
\text { (Foster, 2007: 14). }\end{array}$ \\
\hline 2008 & $\begin{array}{l}\text { - There is great interest and envisaged potential in social technology and } \\
\text { Web } 2.0 \text { tools and techniques - but not much serious deployment yet } \\
\text { (Foster, 2008: 13) }\end{array}$ \\
\hline 2009 & $\begin{array}{l}\text { - Rolling back of desk-top deployment of data sources in some companies } \\
\text { due to financial pressures and non-use; other companies continue to } \\
\text { expand desk-top access to information products (Foster, 2009: 10). } \\
\text { - Social technologies for corporate deployment - a third of respondents are } \\
\text { believers, a third agnostics and a third atheists (Foster, 2009: 11) }\end{array}$ \\
\hline 2010 & $\begin{array}{l}\text { - The business benefits of the use of social media is still doubted by some } \\
\text { companies (Foster, 2010: 8). } \\
\text { - Blogging, wikis and personal networking tools are being used to a greater } \\
\text { or lesser extent by } 80 \text { per cent of respondents (Foster, 2010: } 8 \text { ). } \\
\text { - Use of mobile data devices - 3G phones, PDAs, and so on - encouraged } \\
\text { by most companies although there are few implications for information } \\
\text { services (Foster, 2010: 9). }\end{array}$ \\
\hline 2011 & $\begin{array}{l}\text { - Information and technology vendors push mobile data products to a } \\
\text { lukewarm audience Foster, 2011:8) }\end{array}$ \\
\hline 2012 & $\begin{array}{l}\text { - Mobile digital devices - expand tailored information delivery and service } \\
\text { support (Foster, 2012: 9). }\end{array}$ \\
\hline 2013 & $\begin{array}{l}\text { - Very little involvement of information professionals so far in Big Data } \\
\text { projects (Foster, 2013: 8). }\end{array}$ \\
\hline 2014 & $\begin{array}{l}\text { - Great majority interested or have an early involvement in big data and } \\
\text { data analytics initiatives. But uncertainty whether and how the information } \\
\text { service quite fits in (Foster, 2014: 14). } \\
\text { - Major potential new role in curating big data and analytics (Foster, 2014: } \\
\text { 14). }\end{array}$ \\
\hline 2015 & $\begin{array}{l}\text { - Movement towards 'anytime, anywhere, any device' access to information } \\
\text { and data (Foster, 2015: 10). }\end{array}$ \\
\hline 2016 & $\begin{array}{l}\text { - Internal social media projects figured highly in current activities (Carter, } \\
2016: 9 \text { ). }\end{array}$ \\
\hline 2017 & $\begin{array}{l}\text { - Realising the potential from connecting and linking data and datasets } \\
\text { creatively is a work in progress for information professionals across all } \\
\text { sectors (Carter, 2017: 122). }\end{array}$ \\
\hline 2018 & $\begin{array}{l}\text { - Al is rapidly impacting the information profession: Al projects described } \\
\text { by information teams range from pilot to fully-implemented (Carter, 2018: } \\
\text { 99). } \\
\text { - As new technological solutions, such as Al and machine learning are } \\
\text { introduced then there will be an increased importance of digital and } \\
\text { information literacy (Carter, 2018: 99). }\end{array}$ \\
\hline
\end{tabular}

\section{Bibliography: BIR Annual Surveys}

Headland Press (1991), Business Information Resources 1991 Survey, Business Information Review, 8 (1): $11-21$. 
Headland Press (1992), Business Information Resources 1992 Survey, Business Information Review, 9 (1): 3 - 13.

Headland Press (1993), Business Information Resources 1993 Survey, Business Information Review, 10 (2): 2 - 13.

Headland Business Information (1995a), Business Information Resources Survey, Business Information Review, 11 (3): 2- 15.

Headland Business Information (1995b), Business Information Resources Survey, Business Information Review, 12 (2): 2-28.

Smith, G. (1997), Business Librarians Embrace the Internet: Annual Business Information Resources Survey, Business Information Review, 14 (1): 1 - .

Smith, G. (1998), Annual Business Information Resources Survey 1998, Business Information Review, (1): 5-21.

Smith, G. (1999), Business Information in the Internet Age: The Annual Business Information Resources Survey 1999, Business Information Review, 16 (1): $5-23$.

Smith, G. (2000), Business Information in Transition: The Business Information Resources Survey 2000, Business Information Review, 17 (1): 5 - 21.

Smith, G. (2001), The New Information Economy Takes Shape: The Business Information Resources Survey 2001, Business Information Review, 18 (1): 5 - 23.

Foster, A. \& Foster, P. (2002), Business Information in the End-User Age: Business Information Resources Survey 2002, Business Information Review, 19 (1): 5 - 22.

Foster, A. \& Foster, P. (2003), Empowering the End-User: Business Information Resources Survey 2003, Business Information Review, 20 (1): 5 - 24.

Foster, P. \& Foster, A. (2004), Delivering Services Under Financial Pressure: Business Information Resources Survey 2004, Business Information Review, 21 (1): 13 - 35.

Foster, P. \& Foster, A. (2005), Adapting to Change: Business Information Resources Survey 2005, Business Information Review, 22 (1): 15 - 37.

Foster, P. \& Foster, A. (2006), Stability is not Immobility: Business Information Resources Survey 2006, Business Information Review, 23 (2): 83 - 107.

Foster, A. (2007), Moving Up the Value Chain: Business Information Resources Survey 2007, Business Information Review, 24 (1): 13 - 29.

Foster, A. (2008), Business Information Survey, Business Information Review, 25 (1): 13 - 35.

Foster, A. (2009), Battening Down the Hatches: Business Information Survey 2009, Business Information Review, 26 (1): $10-27$.

Foster, A. (2010), The Boss Just Said 'Do More with Less!': The Business Information Survey 2010, Business Information Review, 27 (1): 8 - 26.

Foster, A. (2011), Let's Save the Company Money - the New Orthodoxy: The Business Information Survey 2011, Business Information Review, 28 (1): 8 - 24. 
Foster, A. (2012), Let's Integrate - Information Services, Content, Technologies, and

Collaboration: The Business Information Survey 2012, Business Information Review, 29 (1): 9 28.

Foster, A. (2013), Add Value or Die: The Fate of Corporate Information Services: The Business Information Survey 2013, Business Information Review, 30 (1): 8 - 26.

Foster, A. (2014), The Game is Changing: The Business Information Survey 2014, Business Information Review, 31 (1): $14-40$.

Foster, A. (2015), 'Moving the Corporate Needle' - How Are We Doing: the Business Information Survey 2015, Business Information Review, 32 (1): 10 - 37.

Carter, D. (2016), Demonstrating a Commercial Mindset: The 2016 Business Information Survey, Business Information Review, 33 (1): 9 - 18.

Carter, D. (2017), Creativity in Action - the Information Profession is Poised to Exploit the Fourth Industrial Revolution: The Business Information Survey 2017, Business Information Review, 34 (3): $122-137$.

Carter, D. (2018), How Real is the Impact of Artificial Intelligence? The Business Information Survey 2018, Business Information Review, 35 (3): 99 - 115.

\section{Bibliography: Other cited works}

Andretta, S. (2005), Information Literacy: a practitioner's guide, Oxford: Chandos Publishing.

Kuhthau, C. (1991), Inside the Search Process: Information Seeking from the User's Perspective, Journal for the American Society of Information Science, 45 (5): 361 - 371.

Reuters Business Information (1996), Dying for Information: an investigation into the effects of information overload in the UK and worldwide, London: Reuters.

Rogers, E. \& Shoemaker, F. L. (1971), Communication of Innovations: A Cross-Cultural Approach, London: Collier MacMillan.

Shirky, C. (2009), Here Comes Everybody: how change happens when people come together, London: Penguin. 